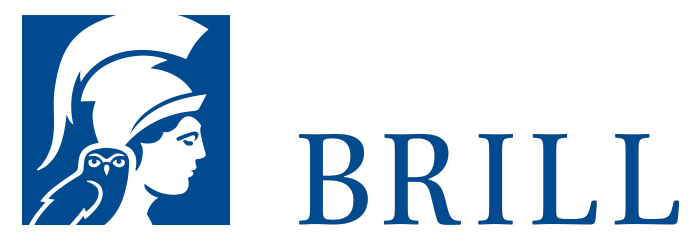

\title{
Eigensinn des Alters
}

Literarische Erkundungen

Author: Hans-Georg Pott

Was heißt: Gutes Leben im Alter? Welche Beispiele für gelungene und misslungene Lebensformen des Alter(n)s bietet die Literatur-geschichte? War es früher an-ders als heute? Was bedeuten Würde und Selbstbestimmung im Alter? Alter(n) als Lebenskunst will gelernt sein und dabei kön-nen die Erfahrungen der Literatur helfen, einen selbstbestimmten Zugang zu finden. Das gilt nicht nur für die Alten, sondern auch für die Jungen. Hans Georg Potts neues Buch behauptet seinen Platz in der Vielzahl von Publikationen zum Thema ,Alter' und ,alternde Ge-sellschaft' darin, dass es einige der oft erwähnten, aber selten oder nie genau gelesenen, gro-ßen' Werke und Schriften zur Altersthematik einer ins Einzelne gehenden nachdenkenden Lektüre unterzieht. Im Unter-schied zu Schriften zur alternden Gesellschaft und zum demographischen Wandel, in Abgrenzung auch zu ,subjektiven' Erfahrungsberichten über das Altwer-den, wird von alten Menschen in der Literatur erzählt, von denen in allen Kulturen und zu allen Zeiten, seit es schriftliche Auf-zeichnungen gibt, berichtet wird. Das Erbe der Antike ist für dieses Thema vorbildlich, aber nur, weil es heute anders ist und also Al-ternativen aufgezeigt werden können. Im Mittelpunkt der Er-kundungen steht der einzelne alte Mensch, sein Wille und seine Würde, und nicht die ,Alten', wie sie lediglich als eine kritische Masse von... See More

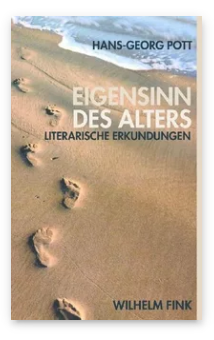

Pages: 195

Seiten

Language:

German

Subjects:

General,

Literature and

Cultural Studies

Publisher: Brill |

Fink

E-Book (PDF)

Released online:

29 Oct 2019

ISBN: 978-3-

8467-4595-3

List price

USD \$28.0o

Hardback

Publication date:

2o Feb 2008

ISBN: $978-3^{-}$

7705-4595-7

List price

USD $\$ 28.00$ 
For more information see brill.com

Order information: Order online at brill.com +44330 333 0049 | customerservices@brill.com Submission information: brill.com/authors

Titles published by Brill | Fink, Brill | mentis or Brill | Schöningh: +49(o)715413279216| brill@brocom.de 